\title{
WOKÓŁ WYSTAWY POLONIA. LES POLONAIS EN FRANCE DEPUIS 1830 W MUZEUM HISTORII IMIGRACJI W PARYŻU — REFLEKSJE I DYLEMATY KURATORA
}

Choć nie jest w zwyczaju pisanie autorecenzji, to jednak pozwoliłam sobie nadużyć przychylności kolegium redakcyjnego „Archiwum Emigracji”, by zgodziło się na opublikowanie poniższego tekstu. Wystawa o historii polskiej imigracji do Francji, jaka miała miejsce od 2 marca do 27 sierpnia 2011 r. w paryskim Muzeum Historii Imigracji, była według mnie wydarzeniem ważnym, zarówno z punktu widzenia naukowego, jak i kulturalnego i politycznego. Mogła z całą pewnością odegrać jeszcze większą rolę, gdyby odpowiednie czynniki polskie wyraziły taką wolę. Po raz kolejny w historii stosunków kulturalnych polsko-francuskich współpraca nie ułożyła się. Przyczyn takiego stanu rzeczy było zapewne wiele. Zapewne również „winy” szukać można po obu stronach. Nie o to mi jednak chodzi. Chodzi mi o to, by to ważne wydarzenie nie uszło uwagi polskich badaczy. Była to pierwsza wystawa tej rangi i o tak dużym rozmachu, przygotowana przez ekipę francuską i proponująca widzowi historię polskiej imigracji widzianą francuskimi oczami, niejako od wewnątrz.

Byłoby niewątpliwie bardzo dobrze, gdyby wystawę tę skomentowali polscy specjaliści, z czysto polskiego punktu widzenia. Byłby to rodzaj konstruktywnego dialogu. Ponieważ jednak, jak do tej pory się tego nie doczekaliśmy, proponuję polskim kolegom garść uwag i refleksji nad wystawą, starając się je ująć we francuskiej perspektywie. Zaznaczam, że uwagi te są czysto subiektywne, a ja nie reprezentuję żadnego oficjalnego stanowiska, ani w stosunku do innych komisarzy, ani do Cité nationale de l'histoire de l'immigration.

Dodatkową przyczyną, dla której chciałam podzielić się moimi uwagami z czytelnikiem w Polsce, jest specyficzna pozycja, jaką zajmują badacze, działający na emigracji. Ich poglądy nie reprezentują już myśli „z kraju”, ale nie są też odbiciem sposobu

\footnotetext{
${ }^{1}$ Wystawa Polonia. Les Polonais en France depuis 1830, Narodowe Muzeum Historii Imigracji w Paryżu, 2.03-27.08.2011. Wystawie towarzyszył obszerny katalog: Polonia. Des Polonais en France de 1830 à nos jours, Paris [2011].
} 
myślenia przedstawicieli swej nowej ojczyzny. Są one niejako „trzecim” głosem w dyskusji, w której uczestniczy tylko dwóch rozmówców. Odgrywają oni bowiem rolę, określaną po francusku jako passeur — pośrednik lub mediator. Moje zainteresowania od wielu już lat nie ograniczają się wyłącznie do poznania i udokumentowania działalności polskich artystów czynnych na obczyźnie, szczególnie we Francji. Idą one w kierunku rozpoznania tego, co nazwać można dyplomacją kulturalną, czyli promowaniem, czy propagowaniem kultury lub sztuki danego kraju zagranicą. Zauważyć bowiem należy, że obok stosunków gospodarczych czy politycznych, jakie wiążą ze sobą dwa kraje, nawiązują się, najczęściej już wcześniej, stosunki kulturalne. Kultura staje się kartą wizytową, jaką one między sobą wymieniają. Często od jakości tej karty zależą przyszłe wzajemne relacje. Poznanie wzajemnych kultur i odrębności pomaga w podtrzymywaniu udanej i owocnej wymiany na innych polach. To „eksportowana” kultura zapisuje się w zbiorowej pamięci społeczeństwa partnerskiego kraju i jest podstawą kształtujących się stereotypów, że „osoby tej narodowości są takie a takie”. Nie należy również zapominać, że w krajach, w których polska obecność, zwłaszcza liczebnie istotna, jak np. we Francji czy w Stanach Zjednoczonych, stereotypy na temat Polaków już istnieją. Nie jest więc do końca celowym propagowanie tam najnowszych osiągnięć artystycznych czy kulturalnych, w oderwaniu od historii, zwłaszcza historii wspólnie przeżytej, czyli polskości, czy polskiej kultury przyniesionej do danego kraju przez pokolenia imigranckie. Czy się tego chce czy nie, imigranci są pośrednikami, czy mediatorami i kształtują opinie o kraju swego pochodzenia, bez względu na to, czy jakieś czynniki oficjalne się temu przeciwstawiają czy nie. Byłoby więc może użyteczne wykorzystanie tych naturalnych pośredników w kształtowaniu stereotypów, czy opinii, które są dla nas pożądane. Wystawa o polskiej imigracji stanowiła niewątpliwie taką okazję. Jak się okazuje, chyba niewykorzystaną.

Dziwną koleją losu, a raczej wskutek decyzji politycznej, kierującej się poczuciem swoistej sprawiedliwości dziejowej, wzniesiony z okazji Wystawy Kolonialnej w 1931 r. w Paryżu Pałac Kolonialny (Palais des Colonies) przy bramie Picpus (obecnie Porte Dorée, czyli Złocona Brama), na wschodnich obrzeżach Paryża, w pobliżu Lasku Vincennes, mieści od niedawna instytucję naukowo-kulturalną poświęconą zjawisku imigracji do Francji, czyli tzw. Cité nationale de l'histoire de l'immigration. Wystawa Kolonialna 1931 r. była również wynikiem decyzji politycznej — jej celem było ukazanie Francji jako kolonialnego imperium u szczytu swej potęgi. Zasadniczym przesłaniem zorganizowanej na wzór wystaw światowych, imponującej rozmachem i przestrzenią, zaaranżowanej z fantazją, a nawet ekstrawagancją, ekspozycji była satysfakcja, jaką z tzw. kolonializmu pokojowego, przynoszącego wyłącznie zyski i szczęście, czerpały obie strony: kolonizatorzy i kolonizowani. Bogaty program ikonograficzny, zrealizowany zarówno $\mathrm{w}$ architekturze, jak i zagospodarowaniu pejzażowym (z tej okazji utworzono nawet ogród zoologiczny, w którym pokazywano zwierzęta z podbitych krajów) ukazywał szerokiej publiczności rozmaitość i ogrom bogactw płynących $\mathrm{z}$ kolonii do metropolii z jednej strony, a pomoc metropolii w rozwoju technicznym, gospodarczym i intelektualnym terytoriów zamorskich $z$ drugiej. Wystawa miała również przekazywać idee jedności metropolii i kolonii, i skłaniać do ich postrzegania jako jednego wspólnego organizmu politycznego. Miała ona uświadomić przeciętnemu Francuzowi, że jego ojczyzna nie ogranicza się wyłącznie do europejskiego Sześciokąta (Heksagonu), ale posiada niezmierzone zamorskie terytoria. Ich różnorodność oddawały zbudowane na potrzeby wystawy pawilony, których styl czerpał inspiracje z architektury poszczególnych należących do Francji krajów. I tak np. Indochiny reprezentował pawilon, którego forma i skala nawiązywały do słynnej kambodżańskiej świątyni 
Angor Vat. Odtworzono całe egzotyczne wioski, w których czekały na zwiedzających rozmaite atrakcje, oparte na kulturze i folklorze podbitych ludów, np. pracujący tradycyjnymi metodami rzemieślnicy lub tańczący wieśniacy w strojach lokalnych. Do dziś zachował się z całego kompleksu wystawy tylko Pałac Kolonii, zbudowany w stylu art déco $\mathrm{z}$ bogatą dekoracją rzeźbiarską w postaci wysokich reliefów pokrywających fasady oraz wielkoformatowych malowideł ściennych wewnątrz. Aż do 1960 r. w pałacu mieściło się Muzeum Kolonii, którego zmieniające się oficjalnie nazwy nawiązywały do konceptu Zamorskiej Francji ${ }^{2}$. W 1960 r., wraz z uzyskaniem niepodległości przez większość francuskich kolonii, muzeum musiało zmienić profil. Przekształcono je w Muzeum Sztuk Afryki i Oceanii, podniesione w 1990 do rangi muzeum narodowego, którego misją było propagowanie sztuki nie-zachodniej. Jednak otwarcie w $2003 \mathrm{r}$. nowego Musée du quai Branly, które przejęło, a nawet rozszerzyło misję Muzeum Sztuk Afryki i Oceanii, spowodowało zamknięcie byłej instytucji kolonialnej. W podziemiach kolonialnego pałacu pozostało tylko akwarium, którego niektórzy mieszkańcy, a zwłaszcza wiekowy krokodyl, pamiętali świetność wystawy 1931 r. W kontekście rosnącej imigracji i związanych z nią problemów, zwłaszcza integracyjnych, w 2004 r. rząd francuski podjął decyzję o powołaniu do życia Narodowej Instytucji Historii Emigracji z siedzibą w dawnym pałacu. Jej oficjalna inauguracja miała miejsce trzy lata później.

W skład Narodowej Instytucji Historii Imigracji wchodzi nie tylko muzeum, oferujące widzowi zarówno ekspozycję stałą, jak i wystawy czasowe, ale także komórki, które wypełniają zadania naukowo-badawcze, kulturalne i pedagogiczne. Funkcje te realizowane są za pośrednictwem publikacji, konferencji i sesji naukowych. Bogatą dokumentacją multimedialną na temat imigracji służy biblioteka, a właściwie mediateka. Na program kulturalny instytucji składają się, obok wystaw, także spektakle muzyczne, baletowe, filmowe, teatralne i literackie.

Wystawa stała, zajmująca przestrzeń $1200 \mathrm{~m}^{2}$, przedstawia dwa stulecia imigracji rozmaitych nacji do Francji. Z punktu widzenia pojedynczego imigranta, każda historia — jego historia — jest indywidualna i jedyna w swoim rodzaju. Z punktu widzenia imigrantów jednej nacji ich historie są podobne, łączą się na ogół z wydarzeniem, bądź sytuacją, które zadecydowały o tym, że podjęli ryzyko opuszczenia własnego kraju. Historie te natomiast są zupełnie inne od historii imigracji innych nacji. Różnice te dotyczą jednak stanu sprzed samego momentu imigracji. Dotyczą przeszłości. Natomiast z punktu widzenia kraju przyjmującego przybyszów ich historie wpisują się ogólny schemat, bez względu na kraj pochodzenia, kondycji „imigranta”, odznaczającej się specyficznymi, wspólnymi dla wszystkich, problemami. Stała ekspozycja w paryskim Muzeum Imigracji oparta została na tej właśnie przesłance „wspólnoty imigranckiego losu", co pozwala jej uwolnić się od indywidualizmu poszczególnych mniejszości narodowych i prowadzić dyskurs ogólny, który rozwija się w trzech zasadniczych częściach. Dyskurs ten jest początkowo anachroniczny. Chronologia włącza się W narrację dopiero wewnątrz poszczególnych części. Pierwsza z nich poświęcona jest samemu doświadczeniu imigracji, powodom opuszczenia ojczyzny, przyczynom wyboru Francji, samej podróży oraz konfrontacji z systemem administracji państwowej i opinii publicznej, często nieprzyjaznych, w nowej ojczyźnie. Część druga opisuje życie imigrantów: miejsca osiedlenia i zamieszkania, pracy, nauki, a także życie wspólnotowe. Mowa tam jest o walce o wspólne prawa, o kwestii uzyskania francuskiego obywatelstwa, o integracji poprzez sport. Ostatnia wreszcie część podnosi kwe-

\footnotetext{
${ }^{2}$ Musée des colonies et de la France extérieure; Musée de la France d'Outre-mer.
} 
stie wkładu poszczególnych kultur, których reprezentanci znaleźli się we Francji, we francuskie życie społeczne, a to za pośrednictwem języka, praktyk religijnych, sztuki, literatury, muzyki, nie zapominając o przedmiotach codziennego użytku. Wystawa pomyślana jest jako całość multimedialna, z wykorzystaniem tekstu pisanego (tablice objaśniające, dokumenty archiwalne, prasa), dokumentów wizualnych (map, fotografii, dokumentów filmowych, dzieł sztuki plastycznej), a także dokumentów dźwiękowych (nagrania narracji, przemówień, muzyki).

Już w założeniu Muzeum Historii Imigracji nie miało ograniczać się do samej tylko wystawy stałej, ale koncentrować się na wybranych problemach, ujętych w formę wystaw czasowych. Pierwsze $z$ nich: na temat stuletniej historii imigracji hiszpańskiej do Francji oraz na temat uchodźców z Armenii na Bliski Wschód i do Francji w latach 1917-1945, odbyły się jeszcze poza murami remontowanego wówczas przyszłego muzeum. Wystawa inauguracyjna, w 2008 r. nawiązywała do okresu powstania Pałacu Kolonialnego i dotyczyła obcokrajowców we Francji w okresie Wystawy Kolonialnej ${ }^{3}$. Imigranci w liczbie trzech milionów czynili wówczas z Francji pierwszy na świecie kraj pod względem otwarcia na obcych przybyszów. Kolejna duża wystawa „Każdy ma swoich obcokrajowców? Francja-Niemcy od 1871 do dziś” przygotowana we współpracy z Deutsches Historisches Museum w Berlinie, poddawała analizie percepcje obcokrajowców w każdym z tych krajów w perspektywie dramatycznych wydarzeń historycznych, jakich świadkiem był XX w. Była ona również okazją do nawiązania pierwszych kontaktów partnerskich z podobnymi placówkami zagranicą. Z okazji Pucharu Świata w piłce nożnej w 2010 r. zorganizowano ekspozycję na temat wzajemnych relacji pomiędzy sportem, a w szczególności piłką nożną, a imigracją. Jak wiadomo, wielu sławnych piłkarzy francuskich, w tym słynny Raymond Kopa (Kopaszewski, Polak z pochodzenia), wywodziło się z imigracji. Wielkie, przeglądowe wystawy przeplatane były pokazami fotografii na temat imigrantów bądź prezentacjami sztuki współczesnej.

Tak szczegółowe omówienie programu wystawowego paryskiej instytucji było konieczne dla właściwego usytuowania wystawy na temat polskiej obecności we Francji. Jest ona drugą, po hiszpańskiej, wystawą o konkretnej mniejszości narodowej, i sytuuje się przed prezentacjami na temat historycznie pierwszej i bardzo licznej pod koniec XIX i w początkach XX w. imigracji włoskiej, czy zajmującego aktualnie ważne miejsce napływu ludności z krajów Afryki Północnej. Oczywiście, nie należy wyciągać z tego faktu zbyt daleko idących wniosków. Jak wiadomo, wydarzenia, obok przyczyn zasadniczych, historycznych, mają swoje przyczyny nieformalne, które często przeważają.

Prace nad wystawą polską rozpoczęły się w roku 2008. I miała być ona zrealizowana na drodze partnerskiej współpracy francusko-polskiej, podjętej z Instytutem Adama Mickiewicza w Warszawie. Francuscy i polscy specjaliści, z naukowym kuratorem wystawy Janine Ponty i kierownikiem Archiwum Emigracji Uniwersytetu Mikołaja Kopernika w Toruniu, Mirosławem Supruniukiem, zainicjowali wymianę poglądów na temat kształtu przyszłej prezentacji tak, aby mogła ona zainteresować nie tylko francuskiego widza, ale zadowolić również szczególnie czułą na punkcie swojej historii publiczność polską. Miała ona zobaczyć wystawę po jej edycji paryskiej, w salach Zamku Królewskiego w Warszawie. Równocześnie zespół Archiwum Emigracji wraz z piszącą te słowa rozpoczął prace nad wystawą monograficzną polskiej malarki czyn-

${ }^{3}$ 1931, Les étrangers au temps de l'Exposition coloniale, 6.05-8.10.2008, Cité nationale de l'histoire de l'immigration, Paryż. 
nej we Francji, Meli Muter (1876 Warszawa - 1967 Paryż), która wzbogacić miała wystawę historyczną o aspekty artystyczne ${ }^{4}$. Obie prezentacje odbyć się miały w gmachu Muzeum Historii Imigracji w Paryżu. Prace nad wystawą były żmudne, podobnie, jak negocjacje pomiędzy partnerami. Trudno dziś dokładnie powiedzieć, dlaczego ostatecznie nie doszło do realizacji polskiego wydania ekspozycji. Za wcześnie na analizy o charakterze historycznym. Jedno jest pewne - polskie czynniki oficjalne nie przejawiły wystarczającej woli politycznej, by projekt zrealizować wspólnie z Francuzami. Wykazały jednocześnie brak zainteresowania nie tylko historią polskiej diaspory we Francji, ale także jej obecnymi przedstawicielami, dla których tego rodzaju wystawa była swego rodzaju wyróżnieniem pośród innych społeczności mniejszościowych we Francji. Było to również dowodem braku zainteresowania Francją jako partnerem kulturalnym. Zerwanie współpracy pozostawiło więc francuską ekipę kuratorską samą ze wszystkimi kwestiami merytorycznymi, których przedstawienie na wystawie byłoby być może inne, gdyby były one przedyskutowane z kolegami polskimi. Również kwestie organizacyjne, a w szczególności wypożyczenia eksponatów, musiały w większości ograniczyć się do zbiorów, znajdujących się na terenie Francji. Polski wkład utrzymał się jedynie w publikacji towarzyszącej wystawie. Do udziału w niej autorzy zostali zaproszeni niezależnie od współpracy nad wystawą. Również niektóre instytucje polskie (może należałoby o nich powiedzieć polsko-polonijne), działające we Francji, usiłowały utrudnić realizację projektu z powodów, które nie zasługują na to, by się nad nimi rozwodzić. Jak to często bywa, trudności, jakich doświadczyli francuscy organizatorzy wystawy, okazały się znakomitym bodźcem do szukania nowych rozwiązań, penetracji nowych zbiorów i znalezienia nowych eksponatów. Pomimo wspomnianych wyżej trudności 2 marca wystawa została otwarta. Była to pierwsza tak imponująca wystawa — ponad 800 eksponatów — poświęcona niemal dwustuletniej polskiej obecności nad Sekwaną, urządzona przez państwową instytucje francuską, przez francuską ekipę komisarzy. Objęła ona zarówno dokumenty archiwalne, publikacje książkowe i prasowe, obrazy, rzeźby, grafiki, fotografie, afisze, przedmioty codziennego użytku, a także nagrania dźwiękowe i filmowe.

W wyniku dyskusji postanowiono przedstawić na niej okres od 1830, czyli Wielkiej Emigracji do lat 80. XX w. Pominięcie okresu napoleońskiego podyktowane zostało względami teoretycznymi. Polacy, którzy przybyli do Francji, by zaciągnąc się do armii napoleońskiej, nie byli imigrantami według aktualnie obowiązującej definicji, gdyż nie przybyli do Francji z zamiarem osiedlenia. Osiedlenie de facto, choć miało miejsce, było ubocznym efektem, który stosunkowo trudno umiejscowić precyzyjnie w czasie. Warunek osiedlenia spełniali natomiast uchodźcy Wielkiej Emigracji. Data końcowa, jaką przyjęto dla wystawy, były lata 80. XX w., choć nie zostało to sprecyzowane w tytule. Fala imigrantów „Solidarnościowych” była ostatnią wielką falą uchodźczą do Francji, którą można wyraźnie wyodrębnić. Jednocześnie perspektywa historyczna, z której spojrzeć można na imigrantów lat 90 . i tych z początku XXI w. wydaje się niewystarczająca do zachowania koniecznego obiektywizmu i uogólnienia.

Zgodnie $\mathrm{z}$ aktualnymi trendami panującymi w wystawiennictwie, a także wspomnianą wyżej koncepcją ekspozycyjną paryskiego Muzeum Historii Imigracji narracja rozwijała się nie chronologicznie, ale problemowo. Złożyły się na nią trzy zasadnicze części. Pierwsza z nich podejmowała wątek Paryża jako drugiej (a w niektórych okresach historycznych nawet pierwszej) stolicy Polski. Tę szczególną rolę w historii Polski

\footnotetext{
${ }^{4}$ Wystawa malarstwa Meli Muter została zastąpiona wystawą, poświęconą twórczości Romana Cieślewicza „Roman Cieślewicz. Zoom”, 1.02-3.07.2011 r.
} 
odegrał Paryż w okresie Wielkiej Emigracji, kiedy to elita intelektualna, pomimo rozparcelowania większości popowstaniowych uchodźców po zakładach, rozsianych po całej Francji, zdołała osiedlić się w stolicy. Tam też usiłowała podejmować akcje polityczne, zmierzające do odzyskania niepodległości, a także, rozumiejąc wagę zachowania tożsamości i kultury narodowej, cierpliwie odtwarzała rozmaite instytucje narodowe na obczyźnie. Wystawa przypomniała najważniejsze polskie instytucje, założone, bądź zainicjowane przez uchodźców, takie jak Polska Misja Katolicka, Towarzystwo Historyczno-Literackie, Biblioteka Polska na Wyspie Świętego Ludwika oraz Szkoła Narodowa Polska w peryferyjnej w XIX w. dzielnicy Batignolles. Ponieważ wszystkie one działają do dziś, na wystawie pokazano nie tylko ich początki, ale także losy obecne. Nie zapomniano również o narodowej nekropolii, którą stał się z czasem cmentarz des Champeaux w podparyskiej miejscowości Montmorency, gdzie spoczywają zarówno bohaterowie Wielkiej Emigracji, m.in. generał Kniaziewicz i historyk Julian Ursyn Niemcewicz, Cyprian Kamil Norwid, jak i członkowie polskiej społeczności XX w., w tym artyści Olga Boznańska, Bolesław Biegas czy Tadeusz Makowski. Dziewiętnastowieczne grafiki przypomniały splendor Hôtel Lambert, siedziby księcia Adama Jerzego Czartoryskiego, miejsca spotkań zarówno konserwatywnej elity politycznej, jak i wybitnych przedstawicieli życia umysłowego i kulturalnego Wielkiej Emigracji, m.in. Chopina i Mickiewicza. Sylwetki tych ostatnich również zostały przedstawione, głównie zresztą za pośrednictwem ich artystycznych i literackich osiągnięć. Zwiedzający oglądali m.in. wydania twórczości Mickiewicza, pamiętające jego czasy, słuchając płynącej dyskretnie z głośników muzyki Chopina. Po raz drugi Paryż odegrał istotną rolę w kulturze polskiej, dając jej możliwość niezależnego od reżimu komunistycznego rozwoju, w okresie powojennym. Ilustrując drugą połowę XX w. nacisk położono przede wszystkim na Instytut Literacki, czyli paryską Kulturę. Przypomniano również księgarnię Zofii i Kazimierza Romanowiczów i ich Galerię Lambert na Wyspie Świętego Ludwika. Autorzy podkreślili również rolę, jaką odegrała francuska stolica w latach 80 . XX w., kiedy po raz kolejny stała się schronieniem dla polskich uchodźców fali „Solidarnościowej”, a w dramatycznych latach stanu wojennego była centrum polskiej myśli niezależnej i organizacji pomocy rodakom w kraju. Obok plakatów „Solidarnościowych”, zaprojektowanych w Paryżu, widzowie mieli okazję obejrzeć historyczne już sprawozdania telewizyjne z manifestacji, jakie miały miejsce we Francji przeciwko stanowi wojennemu w Polsce, a także usłyszeć przemówienie jednego z najbardziej znanych polskich imigrantów, Andrzeja Seweryna, zagrzewającego Polaków i Francuzów do podejmowania akcji protestacyjnych.

Paryż był również miejscem osiedlania się polskich Żydów, którzy zaczęli doń napływać od lat 80. XIX w., a zwłaszcza w okresie międzywojennym. Zamieszkiwali oni przede wszystkim dzielnicę Marais oraz sąsiednie dzielnice położone na wschód od niej. Trudnili się głównie rękodziełem, jak krawiectwo, szewstwo czy kuśnierstwo, a także handlem, m.in. tradycyjnymi produktami spożywczymi z Europy Środkowej, tworząc własne społeczności, bez wyraźnej łączności z francuskim środowiskiem żydowskim.

Drugą część ekspozycji, największą zarówno pod względem zajmowanej przestrzeni, jak i ilości przedstawionych eksponatów, zajęła historia imigracji ekonomicznej. Jak wiadomo, Francja była jednym z głównych kierunków polskich wędrówek „za chlebem" w początkach XX w. Po I wojnie światowej, kiedy organizowało się i krzepło odrodzone państwo polskie, wykrwawiona Francja przyjęła niemal pół miliona jego obywateli, którzy służyli jej swoją pracą w kopalniach, i to nie tylko węgla na Północy, ale jak słusznie przypomina wystawa, także rud żelaza i potasu w Regionie Central- 
nym, Lotaryngii, Alzacji czy Normandii. Ekspozycja przedstawiła liczne archiwa dotyczące polskich górników, ich pracy, ich adaptacji do francuskiej rzeczywistości, poprzez naukę języka i przystosowywanie się do innych obyczajów. Nie zapomniano również o przedstawieniu przystosowania warunków w nowej ojczyźnie do potrzeb przybyszów, np. wielojęzyczne plakaty, czy broszury w miejscach pracy. Zgodnie z faktycznym stanem rzeczy wiernie odtworzono silne przywiązanie górników do polskich tradycji narodowych i religijnych, wyrażające się w zakładaniu polskich organizacji, stowarzyszeń i kółek, często związanych z wiarą i kościołem katolickim, ale także muzycznych czy sportowych. Osobne miejsce zajęły polskie szkoły oraz polska prasa, w tym słynny, bardzo zasłużony dla zachowania polskości, ukazujący się przez ponad 80 lat dziennik „Narodowiec”. Bardzo wzruszającym i poruszającym rozdziałem W części traktującej o imigracji ekonomicznej był rozdział przypominający polskich robotników rolnych. Źle traktowani, w przeciwieństwie do górników zgrupowanych w polskich „koloniach”, rozsiani po całej Francji, odizolowani jedni od drugich i zdani na łaskę swoich gospodarzy, tym trudniej znosili rozłąkę z rodzinnym krajem i pozostawioną tam rodziną. Szczególnie trudna była sytuacja polskich robotnic rolnych, nie znających języka, często analfabetek. Stawały się one łatwymi ofiarami nadużyć także seksualnych. Obiektywne historyczne dokumenty, papiery osobiste, ale także zdjęcia i nagrane wywiady-świadectwa pozwalały odkryć mało znaną, a do niedawna nawet ukrywaną problematykę.

Ostatnia część wystawy poświęcona była wkładowi i osiągnięciom Polaków, zarówno sławnych i uznanych, jak i całkowicie anonimowych i zapoznanych, na polu militarnym, naukowym i artystycznym Francji. Historia sióstr Skłodowskich, Marii i Broni, posłużyła jako przykład udziału polskich naukowców we francuskim życiu naukowym, od studiów na francuskich uniwersytetach po najwyższe osiągnięcia badawcze. Dokumenty związane z udziałem Polaków w szeregach armii francuskiej, Legii Cudzoziemskiej czy polskich oddziałach wojskowych utworzonych na terenie Francji, a także w ruchu oporu w czasie I i II wojny światowej w imię hasła ,za wolność Waszą i naszą", świadczyły o ich udziale na polu militarnym. Oprócz filmów i dokumentów oficjalnych pokazano wzruszające artystyczne świadectwo ich wojskowego zaangażowania. Młody polski malarz Szymon Mondszajn (Simon Mondzain), przybyły do Francji tuż przed I wojną światową, zaciągnął się, jak wielu jego kolegów, do Legii Cudzoziemskiej i wziął udział w krwawych walkach, m.in. w Szampanii. Rysować nie zaprzestał nawet $\mathrm{w}$ okopach, jak o tym świadczy jego zdjęcie $\mathrm{z}$ frontu w hełmie, ze szkicownikiem w ręku. Wykonane wówczas rysunki pokazano na wystawie. Niektóre z nich, jak Pruska śmierć na koniu, czyli kościotrup w Pikielhaubie z kosą $\mathrm{w}$ ręku, są wyrazistym symbolem poczucia zagrożenia młodego żołnierza. Kilkadziesiąt lat później podobne świadectwo z szeregów armii polskiej we Francji w 1940 pozostawił Sasza Blonder/André Blondel, żołnierz-artysta z Krakowa.

Wystawę zamykała galeria dzieł polskich artystów, tak licznych we Francji na przestrzeni ostatnich dwóch stuleci. Jako komisarz tej części wystawy miałabym ochotę opisać ją szczegółowo. Wobec braku miejsca wspomnę tylko, że spośród dzieł 1200 twórców wybrano około trzydziestu prac, głównie malarskich, przedstawiających francuskie pejzaże od Paryża poprzez Normandię, Bretanię, po Prowansję i wybrzeże Morza Śródziemnego, malowane przez Polaków. Kryterium wyboru przyświecało założenie, że polscy artyści, czynni we Francji nie ograniczają się jedynie do niejako eksterytorialnego Paryża jako centrum sztuki, ale identyfikują się z krajem osiedlenia; podobnie, jak ich francuscy i innych narodowości koledzy mają ochotę lepiej go poznać i przedstawić w swoich pracach. Ich pobyt we Francji nie jest naznaczony nostalgią za 
krajem rodzinnym, o jakiej świadczyłyby polskie pejzaże, ale nadążają za panującymi w międzynarodowym środowisku ,modami”. Prace te pozwalały prześledzić kolejne etapy polskiej obecności artystycznej we Francji od końca XIX w. po lata 80. XX w., od fascynacji francuskim impresjonizmem, widocznej w twórczości Ludwika de Laveaux czy Józefa Pankiewicza, poprzez syntetyzm Ślewińskiego, kubistyczne próby Tadeusza Makowskiego, do abstrakcyjnych, powojennych dzieł Jana Lebensteina, czy mniej znanych artystów emigracyjnych, jak Władysław Łopuszniak czy Witold Januszewski. Część dokumentalna obrazuje m.in. działalność krytyków i marszandów, bez których nie może się obejść żadne środowisko twórcze. Pokazane w tej części portrety i autoportrety były świadectwem wzajemnych bliskich relacji artystów i intelektualistów polskich i francuskich na międzynarodowej scenie Paryża. I tak, pokazano portret francuskiego rzeźbiarza François Pompona pędzla Meli Muter, portret francuskiego krytyka sztuki André Salmona autorstwa Leopolda Gottlieba, wreszcie portret trzech poetów, czyli Guillaume'a Apollinaire'a, Maxa Jacoba i wspomnianego już André Salmona namalowany przez Louisa Marcoussisa (wł. Ludwika Markusa). Marszandów reprezentowali: odkrywca awangardowych talentów, m.in. Soutine'a i Modiglianiego, Leopold Zborowski sportretowany przez Alicję Halicką ${ }^{5}$, oraz Adolf Basler przedstawiony przez Romana Kramsztyka ${ }^{6}$.

Komisariat naukowy wystawy zapewniła specjalistka w dziedzinie historii imigracji polskiej do Francji, autorka szeregu prac na jej temat ${ }^{7}$, wieloletni wykładowca na Uniwersytecie w Besançon, Janine Ponty. Sekundowała jej historyczka, Marie Chominot, oraz pisząca te słowa historyczka sztuki. Wystawa została bardzo starannie przygotowana od strony scenograficznej i oglądanie jej sprawiało widzowi prawdziwą przyjemność estetyczną. Pomimo iż przestrzeń sali wystawowej, dużej, bo zajmującej ponad $600 \mathrm{~m}^{2}$, była trudna i niewdzięczna - wąska i długa, to jednak zastosowane podziały, kody kolorystyczne i stylistyczne inne dla każdej z części, pozwalały zwiedzającym na szybką orientację. Pomocne były również wskazówki historycznogeograficzne na wstępie ekspozycji: krótka, ale trafnie dobrana chronologia pozwalała widzowi usytuować wydarzenia dotyczące historii imigracji polskiej do Francji wobec ogólnie znanej historii Francji i Polski. Mapy pozwalały na prześledzenie zmian, jakim ulegało państwo polskie od czasu ostatniego rozbioru. Wystawę otwierał obraz Józefa Szermentowskiego zatytułowany Lekcja geografii albo Rodzina artysty $^{8}$, będący swoistą alegorią emigracji. Namalowany w 1875 r. przedstawia on salonik typowego paryskiego mieszkania, przez którego otwarte, przeszklone drzwi widać wieże katedry Notre-Dame. Siedząca w centrum kompozycji kobieta ubrana jest na czarno, jakby wciąż jeszcze nosiła żałobę po klęsce powstania styczniowego. Klęskę powstania symbolizuje ołowiany żołnierzyk, który spadł z drewnianego konika. Kobieta trzyma na kolanach rozłożoną mapę Europy, na której wskazuje swemu kilkuletniemu synowi miejsce, w którym powinna znajdować się Polska. Pies, leżący u nóg kobiety, symbolizuje wierność opuszczonej ojczyźnie, a raczej wierność jej pamięci. Młodsze dziecko,

\footnotetext{
${ }^{5}$ Alicja Halicka, Portret Leopolda Zborowskiego, 1914, Archiwum Emigracji (depozyt Bolesława i Liny Nawrockich).

${ }^{6}$ Roman Kramsztyk, Portret Adolfa Baslera (kolekcja Toma Podla).

${ }^{7}$ Janine Ponty jest autorką następujących publikacji na temat polskiej imigracji do Francji: Polonais méconnus: histoire des travailleurs immigrés en France dans l'entre-deux-guerres, Paris 1988; Les Polonais du Nord ou la mémoire des corons, Paris 1995; L'immigration dans les textes: France, 1789-2002, Paris 2004; Les Polonais en France: de Louis XV à nos jours, Monaco 2008 .

${ }^{8}$ Józef Szermentowski, Lekcja geografii (Rodzina artysty), 1875, Muzeum Historii Kielc.
} 
niemowlę, siedzące w wysokim dziecinnym krześle, trzyma w ręku wiatraczek w kolorach Francji. Ponieważ jest ono najmłodszym uczestnikiem sceny, mamy prawo widzieć w nim projekcję artysty, odnoszącą się do przyszłości. Fakt, że dziecko trzyma w ręku zabawkę w kolorach Francji wskazuje niewątpliwie, że artysta, który przedstawił sam siebie w opisywanej scenie w autoportrecie, dominującym całą scenę, utożsamia przyszłość swoją i swojej rodziny z życiem na emigracji we Francji.

O wystawie i instytucji, która ją zorganizowała, można by jeszcze wiele napisać, bo obie na to zasługują. Wystawie towarzyszyła publikacja pod tytułem Polonia. Des Polonais en France de 1830 à nos jours, wydana pod naukową redakcją Janine Ponty. Zbiór artykułów, a nie prawdziwy katalog wystawy, nie zawiera on bowiem listy wystawionych obiektów, objął 34 teksty autorów francuskich, polskich oraz polskich imigrantów do Francji. Bogato ilustrowany, choć nie zawsze reprodukcjami eksponatów, które znalazły się na wystawie, odtworzył on strukturę wystawy i pozwolił na rozszerzenie informacji, które z powodu ograniczonej przestrzeni ekspozycyjnej musiały być siłą rzeczy ograniczone. Publikacja stanie się niewątpliwie kompendium wiedzy o Polakach we Francji na najbliższych kilkadziesiąt lat.

W okresie prezentacji wystawy Polonia ekspozycję stałą i czasową w Muzeum Historii Imigracji obejrzało ok. 28000 zwiedzających. Nie dysponujemy danymi na temat ich profilu. Wiadomo, że przyciągnęła ona mniej publiczności szkolnej niż wystawa na temat relacji pomiędzy piłką nożną a imigracją. Wydaje się to zresztą oczywiste. W kraju, w którym bywają szkoły, do których uczęszczają dzieci i młodzież kilkudziesięciu narodowości, wystawa poświęcona tylko jednej z nich, w dodatku aktualnie nie najważniejszej, nie mogła przyciągnąć tak wielkich szkolnych tłumów, jak wystawa poświęcona „grze w nogę". Postacie piłkarzy z pierwszego lub drugiego pokolenia imigrantów, jak wspomniany już wyżej Kopa, czy bliższy nam czasowo legendarny Zinedine Zidane, są żywym przykładem francuskiego mitu udanej integracji. Polska imigracja, druga co do wielkości po włoskiej, należy dziś do imigracji historycznych. Ostatni raz na pierwszych stronach gazet znalazła się w okresie „Solidarności” i stanu wojennego, czyli 30 lat temu. „Polski hydraulik” wywołał sprzeciw polityków francuskich w 2005 r. właśnie dlatego, że nie miał być imigrantem, a tylko „gościnną” siłą roboczą, funkcjonującą według reguł kraju pochodzenia, a nie osiedlenia. Wystawa rozpoczęła się, zanim Polska objęła prezydencję Unii Europejskiej. Polskie czynniki oficjalne nie włączyły jej więc do planu promocji, związanego z tym faktem. Zresztą, trudno było zauważyć jakieś wyraźne wysiłki polskich czynników oficjalnych w kierunku promocji wystawy we Francji, pomimo, że Instytut Polski w Paryżu był jej oficjalnym partnerem i opracował bardzo interesujący program kulturalny, towarzyszący wystawie. Także otwarcie ekspozycji w okresie, kiedy część gmachu muzeum była okupowana przez nielegalnych imigrantów „bez papierów”, walczących o zalegalizowanie ich prawa do pobytu we Francji, i obecność policji nie ułatwiły promocji.

Przypomnijmy jeszcze kwestie ogólne, związane nie z tematem wystawy, lecz z samym muzeum. Jest to instytucja młoda, licząca zaledwie trzy lata, co w konserwatywnym kraju kwalifikuje ją do kategorii kulturalnych niemowląt. Powołane z powodów politycznych, szukające właściwego profilu, chodzące jak po kruchym lodzie, żeby nikogo nie urazić, być politycznie poprawnym, szukającym zarówno odpowiedniego języka, jakiego powinno używać w wypełnianiu swojej roli, jak i szukającego swojej publiczności. Bo jakkolwiek instytucja jest niewątpliwie potrzebna, to trzeba sobie zadać pytanie, komu właściwie i w jakim celu. Czy mają tam przychodzić Francuzi, by lepiej zrozumieć swoich nowo przybyłych współziomków? Czy też nowi 
przybysze, by odnaleźć swoją tożsamość i kondycję imigranta „nobilitowaną” w muzeum? Czy wreszcie ma ono głównie spełniać rolę edukacyjną, pedagogiczną i nauczyć młodych akceptacji i tolerancji inności? Innymi słowy, przytoczoną wyżej wysoką frekwencję na wystawie zawdzięczać należy zapewne sprawnie działającej „poczcie pantoflowej” w obrębie żywotnej społeczności polskiej oraz jej sile perswazji wobec francuskich przyjaciół. Wśród zwiedzających można było również spotkać obcokrajowców, w tym Polaków z Polski i innych krajów, dla których jedną z trudności był brak opisów eksponatów i tablic objaśniających w języku innym niż francuski. Tego jednak ograniczony po wycofaniu się polskiego partnera budżet nie uwzględniał. Tak czy inaczej, ilość zwiedzających świadczy o sukcesie wystawy.

Warto również zastanowić się nad uwagami, które w tej czy innej formie dotarły do komisarzy. Większość z nich zarzucała takie, czy inne braki wystawie. Uwagi tego rodzaju pochodziły najczęściej od potomków polskich emigrantów do Francji. Przedstawiciele współczesnych pokoleń zachowali w pamięci wersje wydarzeń, czy przeżyć, które opowiedziane lub przekazane im zostały przez przodków. Jest rzeczą właściwie oczywistą, że wersje „rodzinne” wydarzeń najczęściej różnią się od wersji ustalonych przez historyków przy zastosowaniu odpowiedniego aparatu krytycznego i przejścia w rozumowaniu historycznym na poziom uogólnień indywidualnych losów.

Niektóre zarzuty pominięcia były wynikiem niezrozumienia tematu. Według większości zwiedzających tematem wystawy były relacje polsko-francuskie bądź historia Polski od 1830, a nie historia imigracji polskiej we Francji. Pomimo opisania kwestii imigracji żydowskiej z terenów polskich, liczni zwiedzający zarzucali komisarzom fakt nie podjęcia kwestii antysemityzmu polskiego. Nie wdając się w dyskusje nad samą kwestią, należy podkreślić, że problem ten nie wchodził w zakres tematyki wystawy, która badała i relacjonowała zjawiska, odbywające się we Francji. Niezrozumienie przez publiczność pojęcia ,imigrant” było również przyczyną wielu nieporozumień. Nie należy bowiem zapominać, że nie każdy przebywający we Francji Polak był imigrantem.

Ostatnia wreszcie kwestia, którą należy poruszyć to konieczność selekcji zbyt obfitego materiału. Historia Polaków we Francji jest bardzo bogata, obfituje w wiele epizodów, obejmuje rozmaite grupy społeczne, których wystawa nie była w stanie ująć. Ograniczona przestrzeń i konieczność spójności narracji zmuszała autorów do dramatycznych i bolesnych wyborów. Ekspozycja była również terenem starcia się podejścia historyka - operującego na zjawiskach grupowych, społecznych — z podejściem historyka sztuki - skoncentrowanego na zjawiskach indywidualnych - historiach pojedynczych artystów. Wynikiem jednak, jak nam się wydaje, był pluralizm poglądów, prowadzący do bogactwa i różnorodności narracji. Szkoda tylko, że nie mogły one być poddane krytyce polskiego odbiorcy.

Ewa Bobrowska (Francja) 